used as in England. The tail was removed at the third bone from the croup, and was supposed to strengthen the back, with which view Markham agrees. Several pages are given of how to make a white, black, and red star on the face; eleven different methods of causing hair to grow; a chapter on how to make an old horse appear young by burning the tables of the incisors and blowing up the supra-orbital fossæ; and other information of a similar and disgraceful character in connection with slow horses and "jibbers."

In Cavelarice Markham played with fire in hinting at his doubtful transactions with low horse-dealers. In the last pages of the Maisterpeece he casts off the mantle of shame, and reveals himself in his true light. $\mathrm{He}$ accurately gauged the class he was writing for, and knew the information which would sell.

A plate representing the farrier's principal instruments brings this wretched book to a close.

(To be continued.)

\title{
ON A TICK-BORNE GASTRO-ENTERITIS OF SHEEP AND GOATS OCCURRING IN BRITISH EAST AFRICA*
}

\author{
By Eustace Mon'tgomery, Veterinary Pathologist, \\ East Africa Protectorate.
}

THIS disease, which has been referred to in the Annual Reports of the Veterinary Pathologist as "Nairobi sheep disease," is a specific febrile disorder associated with acute gastro-enteritis, the virus of which can be conveyed by the rhipicephalus appendiculatus.

\section{A.-FIELD OBSERVATIONS.}

Distribution.-The disease first came under noticc on 28 th November I9IO, when Mr H. Brassey Edwards, the veterinary officer of the district, reported a mortality among the sheep grazing on the Nairobi commonage, and forwarded a bottle of blood drawn from a case. Sheep are in this country traded from the Masai, Suk, and Turkana countries and the Northern Frontier for disposal to the Kikuyu Native Reserves or to the Nairobi population. A very great number therefore pass through the Nairobi township annually, and the mortality among them while staying there is high.

The Kikuyu Native Reserve near Kabete has been shown to be naturally infected on several occasions between I9IO and I9I5.

In I9I I we obtained evidence of its existence in the Kedong Valley and at Juja near the Athi River.

In I9I 3 cases occurred at Makindu Railway Station, and in the same year many settlers on the Fort Hall Road purchased trade sheep which were passing from Fort Hall towards Nairobi. At purchase the animals appeared healthy, but within a fortnight nearly all died. Positive evidence of this disease was obtained from one farm. 
In 1914 the disease was diagnosed at Kikuyu Station; and it occurred at Voi, Burra, and Maktau among military slaughter sheep in this and the following year.

I have been unable to find that the Kikuyu natives regard the disease as an epizootic or treat it as serious. Their name for it, "Kuharo," simply means diarrhœe, from which, they say, they lose about one-half of the sheep born. They are quite alive to the fact that sheep bought from traders in Nairobi "pick up" this disease in a few days, but this is attributed to local dietetic causes, and not to the fact that the sheep are infected on arrival. The Kikuyu view of East Coast fever, which is also enzootic in their reserve, is similar, the condition not being regarded as serious owing to the immunity of their old stock, the mortality being among calves, and being widely distributed among a large number of small owners.

We have never encountered any immune sheep among those coming direct from the Masai Reserve, or from the Rift Valley and North Kavirondo, and there is reason to believe that those districts are free from infection.

As the direction of trade is away from these centres, it is probable that the disease has not yet had an opportunity of reaching them, and, in addition, it should be noted, the Masai Reserve and the Rift Valley are, in the main, free from East Coast fever, a freedom probably due to a great paucity of the brown tick, rhipicephalus appendiculatus, the transmitter of both diseases.

It may, then, be considered that tick-borne gastro-enteritis of sheep is essentially a disease of the Kikuyu country, which extends from Mount Kenia to Nairobi.

Mortality.-In all cases the following refer to native sheep. It is not possible to obtain accurate figures from the Somali traders, but in the first outbreak recorded by $\mathrm{Mr}$ Brassey Edwards it was stated that 2000 sheep died out of 3000 within one month of arrival.

A settler on the Fort Hall Road who purchased 200 head on 23rd September I9I3 lost I79 in sixteen days.

Of roo sheep brought on to a farm adjoining the laboratory in I9I 5,74 died within one month.

In another instance 250 died out of 350 within one month of arrival on the infected pastures.

Clinical Symptoms.-The first indication of sickness is usually a dulness and tendency to stand apart; the head is held low, and mucus is often discharged from the nose. Shortly afterwards diarrhoea is seen, the faces being green, sometimes containing blood or mucus, and later in the affection are passed with straining and pain. Death occurs usually within two days of the onset of symptoms; the animals rarely live for four days.

The temperature is usually normal from the time objective symptoms appear, but, as will be noted later, it manifests a marked and characteristic curve a day or two before any outward signs are manifested.

Post-mortem Appearances.-The carcase is empty, in poor condition, and shows evidence of diarrhœa and often a blood-stained discharge from the nostrils. 
Acute inflammation is seen in the fourth stomach, the mucosa of which may be coated with blood, and throughout the intestines, especially in the large bowel; the latter is usually empty, its mucous membrane is thrown into longitudinal folds, and the ridges are deeply hæmorrhagic.

The spleen is invariably enlarged, thickened, and dark on section, and the white or lighter coloured Malpighian bodies stand out prominently.

The gall bladder is almost invariably much distended with fluid green bile.

The trachea is commonly deeply congested, and may contain blood-stained mucus, but rarely any froth.

\section{B.-LABORATORY OBSERVATIONS.}

\section{1.-Clinical. (See Charts-Sheep 280, I I 58.)}

Following the inoculation of a susceptible sheep with virulent blood, the temperature rises usually within forty-eight hours to $105^{\circ}$ or $106^{\circ} \mathrm{F}$. The rise is sudden. It remains high-between $105^{\circ}$ and $108^{\circ} \mathrm{F}$.- -for about two days, and then falls suddenly to

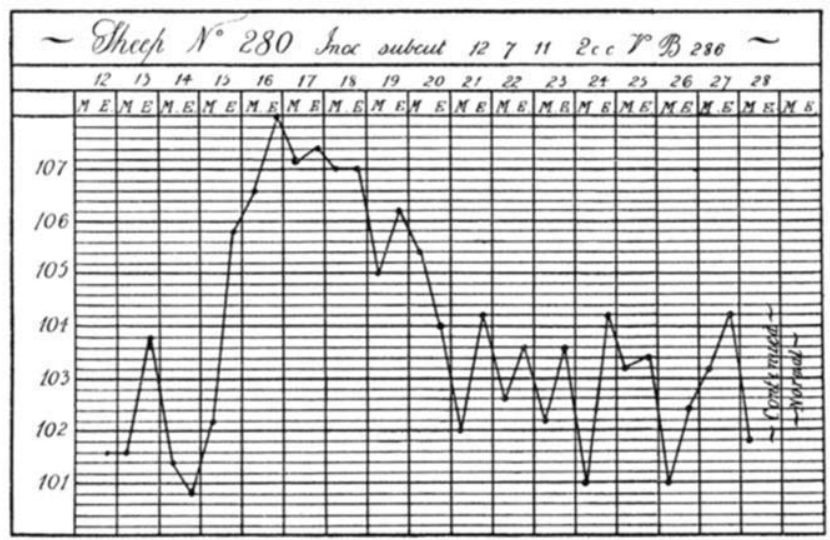

ChanT. Sheep 280.

normal, where it remains for one or two days before death or recovery ensues.

With the original Nairobi strain, the rise occasionally occurred within thirty-six hours, and almost invariably within forty-eight hours. With strains derived from Voi and from Kikuyu the incubation was slightly longer, and in a few cases did not occur until the seventy-second hour, when commonly the suddenness of the rise was less marked owing to an intermediate temperature reading being interposed. With these later strains, too, the duration of reaction was rather longer-up to four days have been noted -and the fall was less abrupt.

The minimum period to the initial rise in temperature was thirtysix hours, the third temperature reading; the maximum was eighty- 
four. This period was somewhat influenced by the method of inoculation, being rather shorter with an intraperitoneal and intravenous than with a subcutaneous.

The minimum duration of the reaction from the initial rise to $105^{\circ} \mathrm{F}$. or over was thirty-six hours; in the majority of animals it was forty-eight to sixty, and in very rare instances it extended to eighty-four hours before the temperature dropped.

The fall at the cessation of the reaction was usually sudden, but in the case of prolonged incubations and reactions the downward line was sometimes broken at one reading, and therefore delayed.

After the fall the temperature usually remains within normal limits for one or two days before death, prior to which the last reading may be subnormal.

Death usually occurs between four and eight days after inoculation; the average in 224 sheep was 148 hours. No deaths took

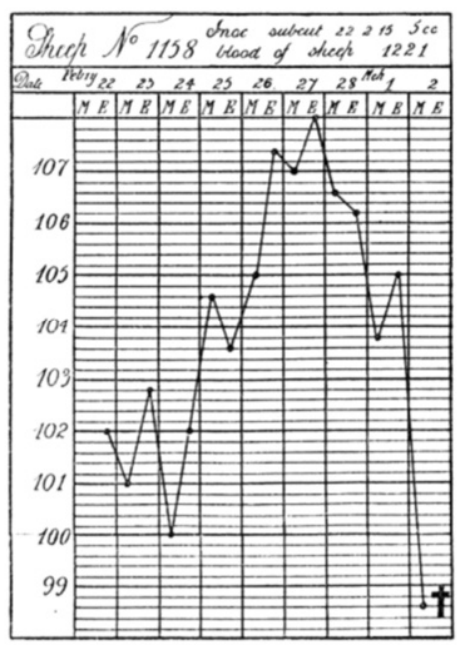

Chart. Sheep 1158.

place before the fourth day, and only five later than the tenth, in none of which were typical lesions present.

Following infection with infected ticks, the incubation period averaged $9^{\circ} 4$ days - minimum 5 and maximum 16 -and the reaction 3.6 days. The reaction in the suddenness of its onset and rapidity of the decline was similar to the inoculated disease.

No objective symptoms can be noted until about the last day of reaction, when the sheep may appear dull and slightly off feed. From this time the sickness becomes apparent: there is extreme depression, entire loss of appetite, a quick feeble pulse, and an almost involuntary discharge of watery, dark green-coloured faces. The respirations are not always increased in frequency. Considerable pain appears to be associated with defæcation in the later stages, the animal grunting as it strains to pass small pieces of mucus. Blood may be present in the dejecta, but this is not very common.

There is an increased discharge of mucus from the nostrils, and towards death it is tinged with streaks of blood. 
Coma supervenes in fatal cases and sometimes lasts for twentyfour hours before death occurs.

In cases which recover the symptoms noted are usually limited to those of dulness, inertia, and slight anæmia. Diarrhœa in such cases is very rare, and this symptom may be taken as an indication of a fatal termination.

The mortality varies considerably according to the breed of animals experimented upon. The majority of those used by us were native sheep either obtained from the Masai Reserve or bred in the Rift Valley from Masai parents. Grade sheep were also. employed; these were bred in the Rift Valley from Masai female stock and Merino rams. A few Pure-breds were also utilised.

The following figures show the results obtained in the first 224 sheep experimented with :-

\begin{tabular}{|c|c|c|c|c|c|}
\hline Breed. & Total. & Reacted. & Died. & Mortality. & Negative. \\
\hline Masai & I 53 & $15 \mathrm{I}$ & 108 & $715 \%$ & 2 \\
\hline Grade & 58 & 57 & I 8 & $315 \%$ & I \\
\hline Merino & I 3 & I 3 & 4 & $307 \%$ & O \\
\hline & 224 & 221 & 130 & $58 \cdot 8$ & 3 \\
\hline
\end{tabular}

\section{Post-mortem Appearances.}

The lesions present at death, whether from natural infection or experimentally induced through ticks or by inoculation, are very constant and vary only in degree.

External Appearances.-Body in poor condition ; empty. Thighs and quarters soiled with dejecta. Congestion of the labiæ vulvæ in ewes. Mucoid and often blood-tinged discharge from nostrils.

Peritoneal Cavity.-No excess of fluid. Intestinal tract appears. empty and the portal system congested.

Abomasum.-Contents usually fluid and often dark in colour from blood admixture. The mucosa is deeply hyperæmic, especially over the folds, which are rarely odematous but frequently show actual hæmorrhage from innumerable petechial points. Towards the pylorus patches of hyperæmia or areas of submucous ecchymoses are present. In two cases the organ contained practically pure blood.

Small Intestine.-Usually empty or containing only fluid ingesta. The mucosa shows a variable degree of hyperæmia, more marked towards the large bowel, and is usually odematous. The lymphoid tissue is swollen and surrounded by a hyperæmic zone.

Large Intestine.-The cæcum and colon are generally empty, or contain a small amount of thick, syrupy, foetid fæces. The mucosa is swollen, and when thrown into folds exhibits pronounced longitudinal hæmorrhagic striæ. When the organs contain fæces the mucosa is studded with fine petechiæ.

Liver.-Is usually normal or slightly congested. The gall bladder is almost invariably distended with clear green bile, which varies in amount from 60 to $125 \mathrm{cc}$. The mucosa of the gall bladder is frequently petechiated.

Spleen.--Is always enlarged, dark, and thickened. On section 
the pulp is relatively firm and the Malpighian bodies stand out prominently.

Thoracic Cavity.-Does not contain an excess of fluid.

Lungs.-Are usually normal.

Trachea and Bronchi.-Are nearly always hyperæmic, sometimes showing hæmorrhage, the lesion being more marked towards the bifurcation.

Heart.-Is commonly petechiated under the epicardium, and the endocardium shows ecchymoses.

Pericardium.--Rarely contains more than a few cubic centimetres of clear fluid ; $20 \mathrm{cc}$. was obtained on one occasion only.

Lymphatic Glands.- Throughout are enlarged and oedematous or congested.

\section{II.-Animals Susceptible.}

Sheep.-Unless sheep have been obtained from a highly enzootic area, and possess an acquired immunity, no difficulty has been experienced in infecting Masai sheep from the Reserve and the Rift Valley, Grade and Pure-bred from the Rift Valley, and native sheep from North Kavirondo.

Out of 224 tabulated sheep, negative results occurred in only three, or I' 3 per cent. All the rest reacted to infection, the mortality, however, varying according to the breed.

Goats. - Twenty goats, the majority Grade Angora from the Rift Valley, have been inoculated. One was negative.

In three there was no temperature reaction, but in two of these

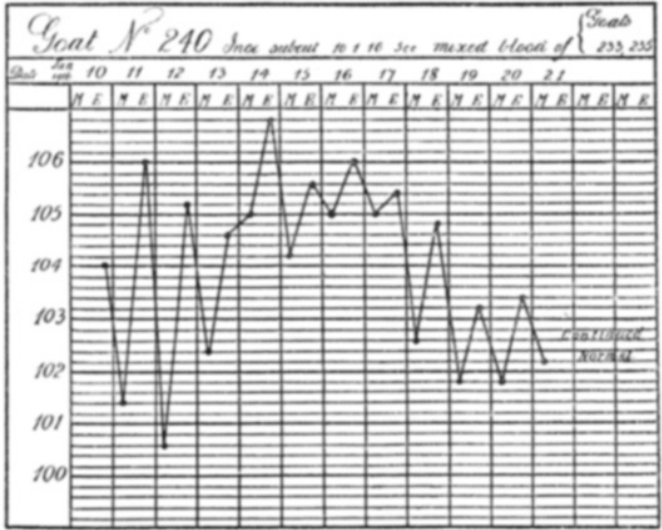

Chart. Goat 240.

the virus was shown by subinoculation to exist. The third died on the sixth day without manifesting lesions.

In five the temperature reaction was very slight and no symptoms were shown, but the blood was proved virulent on inoculation. One of these died from pleuro-pneumonia on the eighth day. The remaining four recovered without further symptoms. (Chart, Goat 240).

Eleven behaved in a similar manner to sheep, but the reaction $\mathrm{C}$ 
was rather more prolonged and the onset delayed about a day. Two goats died of gastro-enteritis, one on the sixth and one on the eleventh day.

Eliminating the two deaths from other causes, the mortality in these goats was io per cent.

The symptoms shown were much more mild than in the case of sheep; diarrhoa was noted in five only and was of a transitory character. In the goats which died tenesmus and abdominal pain was less marked, and the disease appeared more subacute in its course.

On autopsy similar pathological changes were present but of a less hæmorrhagic nature.

Cattle.-Eight oxen, including an imported English animal, four Grade animals from different parts of this Protectorate, and three from Uganda, some of which were susceptible to rinderpest and bovine ephemeral fever, were inoculated together with controls on different occasions between 20th December I9IO and 26th January I9I5.

No temperature reaction was recorded, and no symptoms were manifested.

Subinoculations made from these cattle at varying periods after inoculation were negative, except on one occasion, when IOO cc. blood withdrawn from $\mathrm{Ox}$ 953, twenty-four hours after an intravenous inoculation with $100 \mathrm{cc}$. of virus, reproduced infection in a sheep. A similar experiment with blood from this ox on the fourth day was negative.

Buffalo.-One Indian buffalo bred at the laboratory showed neither temperature reaction nor symptoms, and its blood was not virulent on subinoculation.

Horses.-Two Arab horses and one Indian horse, all of which had been recently imported, showed neither temperature reactions nor symptoms after inoculation, and their bloods were non-infective.

Mules, Donkeys, and Other Animals.-Three Abyssinian mules, three Suk donkeys, two pigs, two dogs, three rabbits, three guineapigs, two white rats, and two tame mice which received at various times injections of controlled virulent blood manifested no reaction or symptoms.

\section{III.-Materials Virulent.}

I. Blood.-Blood drawn during the thermal reaction has been shown virulent on every occasion, In most of the earlier experiments it was inoculated direct from sheep to sheep, or was collected in citrate solution when a series of inoculations was to be made. Subsequently it was found that the virus was not destroyed by short contact with equal parts of oxalate-carbol-glycerine solution (oxalate of potash 5 grammes, carbolic acid 5 grammes, glycerine $1000 \mathrm{cc}$, and water IOOO cc.). (For duration of virulence in this mixture see Resistance of Virus, page 39.)

Experiments with blood collected at varying periods after the acme of the temperature reaction indicate that the virus may be present for about one day subsequent to the return to normal (see page 39, Resistance of Virus in vivo).

2. Sermm.-Blood drawn during the infective period was clotted, 
and the corpuscle-free serum proved virulent both on direct inoculation and after filtration.

3. Organs.- Saline extracts of organs removed from animals dying with the acute reaction were virulent. When the temperature had been normal for some days, and the clinical symptoms were present, negative results were frequently obtained.

4. Body Fluids. - A single experiment with the fluid obtained from the pericardium of a sheep, which died of the acute disease, was positive.

Three sheep inoculated at two different times with bile collected at death from an acutely-reacting sheep were negative, though in each case the experiment was controlled by the positive reaction in sheep inoculated with blood obtained from the same animal and at the same time.

5. Urine.-These experiments were originally undertaken to ascertain whether infection could be spread on the pastures through the agency of urine.

(a) Urine obtained on post-mortem.-On Ioth August I912 Sheep 47 I was inoculated subcutaneously with Io cc. urine of Sheep 455, just dead from an acute reaction. The bladder had been seared and the contents collected in a syringe, the needle of which punctured a sterilised area.

A reaction commenced on the evening of the third day and lasted for three days, when the temperature fell to death on the eighth day. The post-mortem lesions were those of this disease.

(b) Urine obtained during life.--The urine was collected in tins slung round the penis of male sheep. Inoculations into control sheep were made with blood collected on the same day as the urine.

Two positive results were obtained.

Sheep 476, inoculated subcutaneously, I5th August 19r2, with 50 cc. urine of Sheep 472 reacting, and Sheep 527 inoculated intraperitoneally with $10 \mathrm{cc}$. of Sheep 523 reacting. In both cases the reactions which followed were typical, and subinoculations with their blood proved the disease to be identical.

Six experiments were negative, but in two of the cases the urine was administered per os. Doses of $5 \mathrm{cc}$., IO $\mathrm{cc}$., and $50 \mathrm{cc}$. were employed subcutaneously, and by the mouth $50 \mathrm{cc}$. were given.

Each of these sheep was subsequently tested with virulent blood and shown susceptible.

6. Faces.-Five sheep were drenched with frees obtained on postmortem from animals which died of the disease. The bowel was manipulated to express the dung per anum, the orifice being opened with a speculum and the material collected in glass vessels.

Two of these sheep died on the seventh and eighteenth days respectively without manifesting any temperature reaction, and subinoculations made from one were negative.

Three sheep did not react during twenty days' observation, and were shown susceptible on subsequent testing.

Owing to the possibility of introducing an intercurrent disease in which a Gram-positive diplococcus frequently appeared, direct inoculation with fæces was not attempted, but Sheep 190 and I92 were inoculated on 2nd April I9I I with the filtrate of fæces diluted ten times, strained through Chardin paper, and then filtered through 
a Berkefeld candle. No result occurred, but a control sheep inoculated with a filtrate of the blood of the sheep from which the fæces were obtained, subsequently passed through the same filter candle, reacted normally and died on the seventh day.

Sheep 190 and 192 reacted normally when tested and died of gastro-enteritis.

\section{IV.-Methods of Experimental Infection.}

I. Inoculation.-As a routine practice all inoculations were made subcutaneously over the shoulder or inside the thigh. On no occasion was any difficulty experienced in transmitting the disease regularly and constantly by this method.

Positive results were also obtained by intravenous and intraperitoneal inoculation. No attempts were made by the intratracheal method.

The occurrence of a sporadic case housed among animals which, though infected with this disease, were under suspicion for trypanosomiasis, and were being subjected to frequent blood examinations, caused an experiment to be made to ascertain whether intracutaneous infection could transmit.

The ears of two sheep were shaved and scarified lightly to avoid hæmorrhage, and a drop of citrated virulent blood applied without friction. In both animals a temperature reaction commenced on. the fourth day, and death ensued on the seventh and ninth.

\section{Minimum Lethal Dose.}

\section{Experiment II I. 2Ist April I9I I.}

Sheep 200 and 203 (controls), each inoculated subcutaneously with 5 cc. serum of Sheep I73. Reactions on second and third days, death on the fifth and sixth.

Sheep 182 and 187 , each inoculated subcutaneously with $\mathrm{I}$ cc. serum of I73. No. 182 reacted on the third and died on the fifth day. No. 187 died, cause unknown, two days after inoculation.

Sheep 136 and I76, each inoculated subcutaneously with $O$ I cc. serum of I73. No. I 36 manifested no reaction whatsoever, and was proved susceptible on subsequent testing. No. 176 reacted on the third and died on the sixth day.

Sheep $14 \mathrm{I}$ and 142 , each inoculated subcutaneously with $00 \mathrm{r} \mathrm{cc}$. serum of I73. There was no reaction in either case, and both sheep were proved susceptible when subsequently tested.

\section{Experiment 43I. Ist March I9I5.}

The serum of Sheep 989 was collected and, prior to a filtration experiment, diluted I to 99 with saline solution.

Sheep No. I 195 inoculated subcutaneously with IOOcc. = I cc. virus

\begin{tabular}{|c|c|c|c|c|c|c|c|}
\hline$"$ & $"$ & I I 48 & $"$ & " & $"$ & $\mathrm{IOCC}={ }^{\circ} \mathrm{I} \mathrm{cc}$ & ", \\
\hline$=0 "$ & $"$ & I I 22 & $"$ & "' & $"$ & I CC. $={ }^{\circ} \mathrm{O}$ I $\mathrm{CC}$. & $"$ \\
\hline$\ldots "$ & $"$ & I 229 & $"$ & " & " & ${ }^{\circ} \mathrm{I} \mathrm{cc} .={ }^{\circ} \mathrm{OOI} \mathrm{cc}$. & ", \\
\hline
\end{tabular}

Each inoculation was made independently and with a separate syringe. All the inoculated sheep reacted within three days, and 
death occurred in all cases within seven days, those receiving the smallest dose reacting and dying as quickly as those with the larger. There was no difference in the severity of the reaction, the symptoms, or the post-mortem lesions found to be present.

2. Infection per Os.-(1) On the I 5 th and 27 th February and on

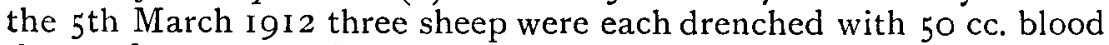
drawn from a reacting animal. Each of the sheep reacted on the fifth day after drenching, and they died of gastro-enteritis on the fourteenth, ninth, and twelfth days respectively.

The post-mortem lesions were typical, and a subinoculation with blood drawn from the animal which died on the fourteenth day showed the reaction to have been due to this disease.

It should be observed that practically every sheep experimented with harboured hremonchi in varying numbers, and their abomasa might therefore be considered as wounded.

(2) On 9th April I9I 5 a sheep was drenched with Io cc. blood of reacting sheep $\mathrm{I} 200$. As no reaction followed within ten days, it was inoculated with $5 \mathrm{cc}$. blood of Sheep 1200 preserved in oxalatecarbol-glycerine for ten days. A normal reaction ensued, and the sheep died on the ninth day.

(3) 9th March I9I2. Two sheep were allowed access, after starving for twenty-four hours, to a rack containing dried lucerne over which IOO cc. virulent blood had been sprinkled.

Reactions commenced on the fifth and sixth days, and the sheep died with typical lesions on the tenth and twelfth.

(4) Ioth August I9I2. Sheep 470, after being starved for twentyfour hours, was fed on grass over which 50 cc. urine obtained on post-mortem had been sprinkled. There was no result.

Fifteen days later the animal was fed with grass over which $30 \mathrm{cc}$. virulent blood had been sprinkled. No result.

Thirty-one days later grass on which $50 \mathrm{cc}$. virulent blood had been sprinkled was fed to this sheep. A temperature reaction commenced on the third day, and death from gastro-enteritis occurred on the ninth.

3. Contact.-(I) Two ewes and their lambs were kept in intimate contact with all experimentally infected animals between Igth December I9Io and I8th February I9I I, living in the same pen and using the same forage and water. No infection resulted, and three of the sheep were shown susceptible on inoculation. (One had died owing to injury from a thermometer:)

(2) Between 6th February and Ist March 1915, five sheep lived in a small paddock 50 feet square, into which a total number of fortyseven inoculated sheep were put from the time the reactions started until death or recovery ensued.

No infection resulted, and all the sheep were subsequently shown susceptible.

It is to be noted that this paddock (No.6 D) had been fenced and unused by any animals for eighteen months, a period sufficiently long to have caused the death of any ticks that might have been present formerly.

4. Through the Agency of Ticks.-This method will be dealt with in extenso under the heading Mode of Transmission (see page 42).

Adult rhipicephalus appendiculatus which fed as nymphæ upon 
reacting sheep are capable of conveying infection. The incubation varies from five to sixteen days in experimental cases; the reaction, course of disease, symptoms, and post-mortem appearances being identical with those observed in animals which had acquired the disease naturally or been infected by inoculation.

\section{V.-Bacteriology.}

Direct microscopical examination is negative; no visible growth occurs in culture made on the usual media maintained under ordinary conditions.

\section{(1) Filtrability of Virus.}

Blood, citrated or defibrinated, plasma obtained by sedimenting corpuscles from a citrate solution, and serum have been used in these experiments.

Dilutions of from I : 4 to I :999 have been made, in the earlier work with saline solution, and in the later with tap water.

Both Berkefeld No. 7 and Chamberland F. control candles have been employed, the dilutions being passed through either by pressure (Chamberland) or by aspiration (Chamberland and Berkefeld). Certain failures to obtain the passage of virus are to be recorded, the reason for which has not yet been ascertained. In all attempts virus controlled by the unfiltered material and shown potent was used. The number of unsuccessful results is small in comparison with the positive ones, and may, I consider, be regarded as due to the use of occluded candles. The following is a summary of the filtration experiments undertaken:-

\begin{tabular}{|c|c|c|c|c|}
\hline & & $\begin{array}{l}\text { Number } \\
\text { Inoculated. }\end{array}$ & Positive. & Negative. \\
\hline \multicolumn{5}{|c|}{ Chamberland $\mathrm{F}$. } \\
\hline \multirow{5}{*}{$\begin{array}{c}\text { Virus. } \\
\text { Citrated blood }\end{array}$} & Dilution. & & & \\
\hline & I $: 4$ & 3 & I & 2 \\
\hline & $1: 9$ & 5 & 4 & $\mathbf{I}$ \\
\hline & I : 99 & 8 & 7 & I \\
\hline & I : 999 & $\mathbf{I}$ & $\mathbf{I}$ & $\circ$ \\
\hline Plasma . & $x: 4$ & 2 & 2 & o \\
\hline Serum . & $\begin{array}{l}\mathbf{I}: 9 \\
\mathbf{I}: 9\end{array}$ & $\begin{array}{r}8 \\
\mathrm{I} I\end{array}$ & $\begin{array}{l}7 \\
9\end{array}$ & $\begin{array}{l}\text { I } \\
2\end{array}$ \\
\hline \multicolumn{5}{|c|}{ Berkefeld No. 7 . } \\
\hline \multirow[t]{2}{*}{ Citrated blood } & I $: 4$ & 2 & I & I \\
\hline & I : 99 & 7 & 5 & 2 \\
\hline \multirow[t]{2}{*}{ Plasma. } & - I $\quad I: 4$ & 2 & 2 & 0 \\
\hline & $x: 9$ & 5 & 4 & I \\
\hline \multirow[t]{2}{*}{ Serum } & - $\quad I: 9$ & 13 & I 3 & 0 \\
\hline & I : 99 & 5 & 4 & $\mathbf{I}$ \\
\hline
\end{tabular}


As a routine practice cultures were made of the filtrate, an equal part being added to three tubes of broth and incubated for fortyeight hours. In three instances growths resulted, but those experiments are not enumerated above. virus.

The following experiments will instance the filtrability of the

\section{Experiment 85 . 23rd February I9II.}

The blood of reacting Sheep IOI is drawn into citrate solution, and the plasma mixed with unsterilised saline to represent a $\mathrm{I}: 9$ dilution of blood. This mixture was passed by aspiration through a new Berkefeld and a new Chamberland F. candle.

Sheep I 26 and I 30 received each $50 \mathrm{cc}$. of the Berkefeld filtrate, and Sheep 127 and 129 each $50 \mathrm{cc}$. of the Chamberland filtrate. Cultural tests of the filtrate showed sterility: a culture of the mixture prior to filtration gave a bacterial growth.

All four sheep reacted normally; one died suddenly on the third day, one died on the fifth, and two on the sixth, the post-mortem lesions being those of hæmorrhagic gastro-enteritis.

\section{Experiment 430. Ist March 1915.}

Blood of Sheep 989 was drawn into a serum flask on 27 th November 19I5, and the serum collected forty-eight hours later. This was diluted to I to 99 of tap water, and passed by pressure through a new Chamberland F. candle.

Sheep I I60, I 2 I9, and I 228 each received subcutaneously $100 \mathrm{cc}$. filtrate (equivalent to I cc. virus), which was sterile in culture.

The reactions in each case were normal; two sheep died on the sixth and one on the eighth day.

\section{(2) Resistance of Virus.}

(a) In Vivo.-A recovered animal is not a reservoir for the virus.

Fifteen tests have been made with blood taken from animals which reacted normally, and whose temperature had been normal for from seven to ten days.

No reactions followed the injection of as much as $100 \mathrm{cc}$. blood, and no protection against subsequent infection was afforded.

The period at which the virus disappears from the circulation is indicated by the following experiment.

\section{Experiment 340. I4th January 1915. (See Chart-Sheep 1042.)}

Sheep 1042 was successfully infected with the blood of a naturally contracted case sent to the laboratory from the Kikuyu country. The temperature reaction is shown on the chart.

Commencing the forty-eighth hour after the acme of the reaction, 5 cc. of blood was withdrawn every twenty-four hours up to the seventh day, and inoculated into sheep considered as susceptible. 


\begin{tabular}{|c|c|c|c|c|c|}
\hline 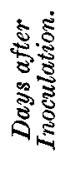 & 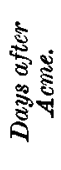 & 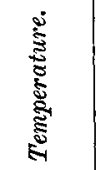 & 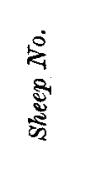 & Result. & Result Test. \\
\hline 5 & 2 & $\dot{103.8}$ & $\mathrm{r} 0 \mathrm{O}_{4}$ & Normal reaction. & - \\
\hline 6 & 3 & IOI & 1003 & $\begin{array}{l}\text { Normal reaction. } \\
\text { Death 6th day. }\end{array}$ & - \\
\hline 7 & 4 & IOI & IOI 7 & $\begin{array}{l}\text { Reaction delayed. } \\
\text { Death }\end{array}$ & - \\
\hline 8 & 5 & IOI 4 & 1006 & Nil & $\begin{array}{l}\text { Normal reaction. } \\
\text { Death } 7 \text { th day. }\end{array}$ \\
\hline 9 & 6 & I02' 6 & $99 I$ & Nil & $\begin{array}{l}\text { Normal reaction. } \\
\text { Recovery. }\end{array}$ \\
\hline 10 & 7 & 103 & 1007 & Nil & $\begin{array}{l}\text { Normal reaction. } \\
\text { Death } 8 \text { th day. }\end{array}$ \\
\hline
\end{tabular}

(b) In Vitro.-In contradistinction to the heartwater of South Africa, the virus of hæmorrhagic gastro-enteritis will live outside the body for more than a very few hours. From our experiments it must be concluded that sterile serum or citrated blood will retain its virulence for about twenty-eight days when exposed to the air, as in plugged flasks, and for up to forty-five days when contained in

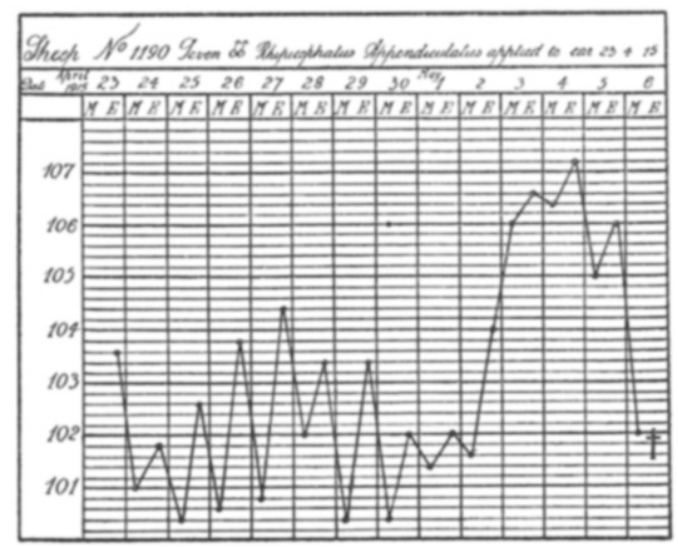

ChaRT. Sheep 1042.

sealed tubes or ampoules. Mixed with equal parts of oxalate-carbolglycerine solution, virulence is retained for about a week.

(I) In Flasks. Citrated Blood.-Sheep No. 32 was bled during the reaction (Igth December I 9 IO) into 5 per cent. solution of citrate of 
soda contained in small flasks of $50 \mathrm{cc}$. capacity, which were kept in a dark chest at about $15^{\circ}$ to $18^{\circ} \mathrm{C}$.

Age of Virus. Sheep Nos.

$\begin{array}{rc}3 \text { days } & 4 \text { I }, 43 \\ \text { I } 2 " & 74,75 \\ 28 " & 93,94 \\ 52 " & \text { IO5, I I } 2\end{array}$

Result.

Normal reactions. Death.

Do.

Do.

Negative No. 105. Susceptible at test.

(2) In Sealed Ampoules. (a) Serum.-The blood of reacting Sheep I94 was collected (28th April I9 I I) in a serum flask, and the separated serum filled into ampoules of IO cc. capacity, which were sealed and stored in the dark at room temperature (about $15^{\circ}$ to $18^{\circ}$ C.)

$\begin{array}{ccc}\text { Age of Virus. } & \text { Sheep Nos. } & \text { Result. } \\ 36 \text { days } & 233,236 & \text { Normal reactions. Death. } \\ 45 " & 247,255 & \text { Do. } \\ 5 \text { I " } & 245,246 & \text { Negative No. 245. Susceptible at } \\ & & \text { test. }\end{array}$

(b) Citrated Blood.-Sheep 1002 was bled (4th November 1915) into citrate of soda solution, and the mixture filled into ampoules of Io cc. capacity which were sealed and stored at room temperature.

\begin{tabular}{rcc} 
Age of Virus. & Sheep Nos. & \multicolumn{2}{c}{ Result. } \\
4 days & I I 3 & Normal reaction. Death. \\
8 Do. & I 64 & Do. \\
I $2 "$ & I 2 I 4 & Do. \\
I6 $"$ & I 99 & Do. \\
$20 "$ & I I98 & Do. \\
$24 "$ & I 50 & Negative. Sheep immune on test. \\
$28 "$ & I 205 & Normal reaction. Death. \\
$33 "$ & I I 55 & Nil. Reaction and death to test. \\
$38 "$ & I059 &
\end{tabular}

(3) Virulent blood drawn into equal parts of oxalate-carbolglycerine solution. Sheep-I9I (25th April I9I I), I042 (7th September 1915), and I 216 (25th February 1915) reacting to inoculation were bled into this solution and the mixture was stored in the dark at room temperature.

\begin{tabular}{|c|c|c|c|c|}
\hline $\begin{array}{c}\text { Age } 0 \\
\quad 7\end{array}$ & $\begin{array}{l}\text { Virus. } \\
\text { ays }\end{array}$ & $\begin{array}{l}\text { Virus. } \\
\text { (I9I) }\end{array}$ & $\begin{array}{l}\text { Sheep Nos. } \\
2 \text { I } 5,2 \text { I } 6\end{array}$ & $\begin{array}{l}\text { Result. } \\
\text { Normal reactions. Death of }\end{array}$ \\
\hline 8 & , & (1216) & I 18 & Normal reaction. \\
\hline I I & $"$ & $(\mathrm{IO} 42)$ & 989 & $\begin{array}{l}\text { Nil, Reaction and death to } \\
\text { test. }\end{array}$ \\
\hline I 4 & " & (I9I) & 219 & Do. \\
\hline 20 & " & (I9I) & 224,228 & Do. \\
\hline
\end{tabular}

(3) Effect of Heat.

I. At $37^{\circ} \mathrm{C}$. (I) Citrated blood 203 sealed and kept in the incubator for forty-two hours. 
Sheep I 37 inoculated 3rd May I9I I with $2 \mathrm{cc}$. showed a pronounced and typical reaction accompanied by symptoms and recovered. The animal was immune to a subsequent test.

(2) Citrated blood 203 dried in vacuo at $37^{\circ}$ for seventy-two hours was inoculated 29th April I9I I into Sheep I 34 and 167 in doses of 25 gramme.

No reaction followed, and both sheep succumbed to the disease on subsequent testing.

2. At $50^{\circ}$ C.-(I) One hour's exposure. Sheep 2 I 2 and $2 \mathrm{I} 3$ each inoculated with citrated blood 203 , kept at $50^{\circ} \mathrm{C}$. for one hour. A normal reaction followed in each case ending in death.

(2) Two hours' exposure. Sheep 250 and 252 each inoculated with citrated blood 233 , kept at $50^{\circ} \mathrm{C}$. for two hours. A reaction, distinct, but delayed, and unaccompanied by symptoms, followed in each case, and the sheep were immune when subsequently tested.

(3) One and a half hours' exposure. (a) Sheep 249 and 256 each inoculated with citrated blood 233 , kept at $50^{\circ} \mathrm{C}$. for one and a half hours.

No. 256 died on the second day, cause unknown. No. 249 showed a very faint temperature reaction, but no symptoms, and was immune when tested.

(b) Seven sheep (Experiment I39) each inoculated with citrated blood 286 , heated at $50^{\circ} \mathrm{C}$. for one and a half hours. Two sheep reacted normally and died; in five animals there was a very faint reaction without symptoms, and when tested four of these were solidly immune. One was susceptible and died after a normal reaction.

(c) Twenty-one sheep (Experiment 139) each inoculated with citrated blood 307, kept at $50^{\circ} \mathrm{C}$. for one and a half hours. Fourteen reacted and died, though in eight the onset and duration were delayed. Seven sheep reacted in temperature, four also showing symptoms, but recovered and were immune.

3. At $60^{\circ}$ C.-Viruses 136 and 220 controlled for virulence at the same time were maintained at $60^{\circ} \mathrm{C}$. for from five minutes to one and a half hours. There was no reaction in any of the sheep inoculated, which with two exceptions were shown susceptible when tested.

\section{VI.-Mode of Transmission.}

It has been demonstrated that cohabitation per se between sick and healthy does not cause the disease to spread, and that consequently the infectivity of urine and faces taken per os play but an insignificant part in nature.

The casual agent of the condition belongs to that group of ultravisible organisms many of which require the intervention of an insect or arachnid host for their transmission.

We have grazed susceptible sheep over pastures believed to be contaminated by the infection, and on every occasion one or more have contracted the disease, even if they were so muzzled as to prevent the animal from eating the grass or drinking the water of that infected area. 


\section{I.--EXPERIMENTS WITH SHEEP GRAZED OVER INFECTED PASTURES.}

\section{(a) Experiment 165.5 th October $19 \mathrm{II}$.}

Sheep 270 and 274 were grazed daily on a portion of the Kikuyu Native Reserve adjacent to the laboratory, where they returned to a clean house at night. From subsequent experience it was learnt that this area could not be very heavily infected, as sheep purchased from some of the villages were not invariably immune.

No. 274 manifested a strong temperature reaction from the fortyfirst to the forty-seventh day, associated with symptoms of facial odema, from which it died. Subinoculations with this blood gave a most definite temperature reaction, accompanied by similar symptoms between the seventeenth and twenty-fourth day. Further subinoculations were negative. The inoculated animal recovered, and, when subsequently tested with gastro-enteritis virus, reacted normally. It is therefore assumed that No. 274 had contracted some other disease.

No. 270 reacted on the ninety-first day after exposure to the pastures, and died of gastro-enteritis nine days later.

\section{(b) Experiment 246. 19th June I9I2.}

The object was to regain a strain of the disease, and consequently the experiment was discontinued when one positive case had been contracted.

Sheep Nos. $425,426,427$ and 428 were grazed daily in the Kikuyu Native Reserve.

No. 425 reacted on the fourteenth day and died 9 days later. Inoculations of its blood into susceptible sheep and into others immune to the disease showed the virus to be that of gastro-enteritis.

\section{(c) Experiment 366. 29th January 1915.}

Early in January 1915 the introduction of one hundred sheep from the Masai Reserve to a farm situated within the Kikuyu Native Reserve was followed by an occurrence of the disease in them, from which seventy-four died. While the epizootic was in progress. three sheep, Nos. IOI4, IOI5, IOI9, were grazed over the pastures by day.

No. IOI9 reacted six days after exposure and recovered after a reaction lasting three days.

No. IOI 4 reacted on the $I$ ith and died on the 14 th.

No. IoI 5 reacted on the 18 th and died on the $23 \mathrm{rd}$.

On 24th February I9I 5, Sheep I I68, I I96 and I 201 were similarly exposed.

No. I 68 reacted on the 6 th and died on the Ioth.

No. I 201 reacted on the 7 th and died on the roth.

No. I 196 reacted on the 9 th and died on the 12 th.

In all these cases death or reaction was due to gastro-enteritis.

\section{I. (d) Experiment 667 .}

For a period of twenty-two days all sheep reacting to the experimental disease induced at the laboratory were put into paddock D6, in which healthy susceptible sheep were living in contact. The last 
death occurred on 28 th February I9I 5 and the in-contact sheep were removed two days later, as, owing to the belief that the condition was tick borne, it was realised that some of the first dropped ticks would be about to moult or the eggs to hatch.

Sheep Nos. I 522 and I 530 were exposed to this paddock on 24th November 1915 , nine months after being vacated.

Seven days later No. 1530 reacted, and No. I 522 followed twentytwo days later. Both sheep were bled to death for virus, which was proved to be that of gastro-enteritis.

\section{II.-EXPFRIMENT WITH MUZZLED SHEEP.}

\section{Experiment 367 .}

Sheep Nos. I029, I032, I033 and I I94 slept at the laboratory in a clean house. Prior to being sent to the infected grazing land with the sheep in Experiment 366 (vide supra), muzzles were attached and sealed so as to prevent the animals eating the grass, and they were not allowed access to the water. On their return in the evening muzzles were removed and they were fed on clean forage.

No. 1029 reacted from the tenth day to the fourteenth.

No. 1032 reacted from the thirtieth day to the thirty-fourth.

No. IO33 reacted from the eighteenth day and died on the twentysecond.

No. I 194 reacted from the sixth day and died on the ninth.

In each case the condition was diagnosed by experiment as gastro-enteritis.

\section{III.-EXPERIMENT WITH GRASS CUT FROM AN INFECTED AREA.}

\section{Experiment 368 .}

Between 29th January 1915 and 23rd March 1915, sheep Nos. 998 , IOO9 and IOI 3 were fed exclusively upon grass cut from the pastures where the sheep in Experiments 366 and 367 were grazing. It should be explained that the grazing was short, turfy, couch grass, well eaten down and difficult to cut, and that in nature sheep neglected the longer growths which occurred close to the village huts, from which the only grass available for house feeding could be cut.

The result in the above three sheep was negative, and this failure is ascribed to the cutting of grass not habitually passed over by infected sheep, and in consequence not containing ticks.

When tested on 23rd March 19I 5 these three animals were proved susceptible to gastro-enteritis.

\section{IV.-EXPERIMENTS WITH TICKS.}

\section{Experiments with Ticks obtained from Naturally Reacting Sheep.}

The sheep which were exposed over infected pastures were examined at intervals, and all replete ticks of different stages which had collected were removed.

(A) In the course of Experiment 366 (vide supra) the following were obtained between $5^{\text {th }}$ February I9I 5 and I 8 th February 19I5, 
during which time all three animals reacted to the disease contracted. naturally.

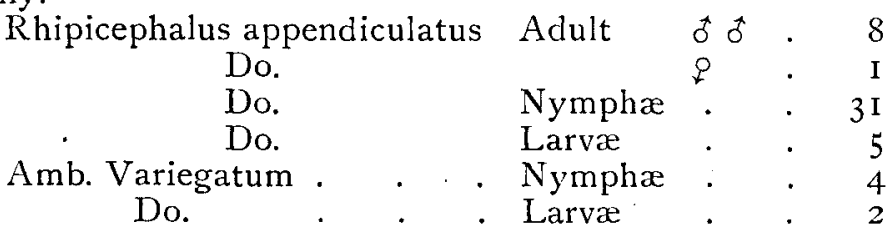

Twenty-six adult rhipicephalus appendiculatus and three adult amb. variegatum emerged from the nymphæ; all the other ticks. collected died prematurely.

Tests.-(a) Experiment 464.-On 27th March 1915, eighteen adult rhipicephalus appendiculatus which fed as nymphæ on reacting sheep in Experiment 366 were applied to Sheep I I 4 I.

The animal died on the seventh day without having manifested any temperature reaction. The autopsy was indicative of gastroenteritis, but the inoculation of three susceptible sheep with blood drawn on the day prior to death was negative.

(b) Experiment 494.-(I) On 23rd April I9I5, seven adult rhipicephalus appendiculatus collected as nymphre from sheep in

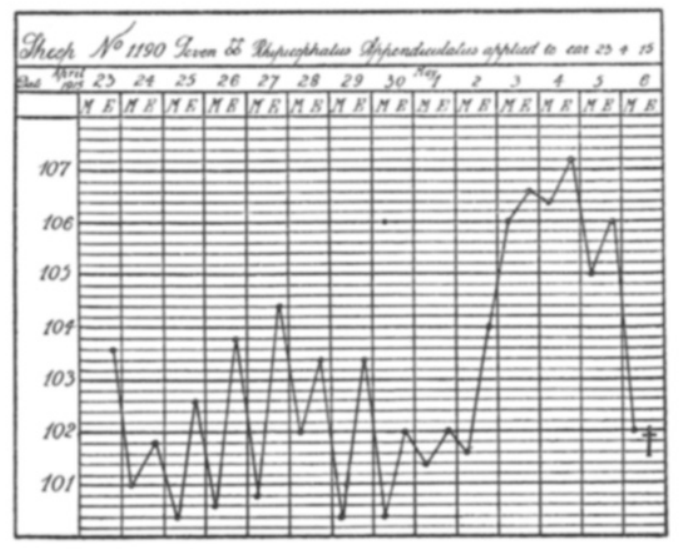

Chart. Sheep 1190 .

Experiment 366 were applied to Sheep I I90. The temperature rose $\left(106^{\circ} \mathrm{F}\right.$.) on the tenth day and death occurred on the thirteenth (Chart-Sheep I 190).

The autopsy was indicative of gastro-enteritis, and subinoculations. made during the reaction proved this disease to be the cause.

(2) On 23rd April I9I 5, two adult amb. variegatum collected as nymphæ from sheep in Experiment 366 were applied to Sheep I 225 .

There was no reaction in twenty-six days, when the sheep was tested for immunity and reacted normally, to die on the seventh day.

Controls.-While this experiment was in progress, two healthy sheep, Nos. I I93 and I334, lived in the same pen as Nos. II90 and 1225 . No reaction occurred in these animals, and No. 1193 reacted normally and died as a result of a subsequent test. 
(B) Experiment 527. - Sheep I349, which had run on a tickinfected pasture without reacting to this disease, was inoculated on I7th July I9I 5 with the virus of gastro-enteritis. A reaction commenced three days later and lasted to the eighth day; death from gangrenous pneumonia occurred a week afterwards.

Five nymphal rhipicephalus appendiculatus were collected on the fourth and eighth day after inoculation. All of these moulted normally.

Test.-Experiment 620. I8th October I9I5. Five adult rhipicephalus appendiculatus which fed as nymphx on Sheep I349 reacting to inoculation were applied to Sheep I5I3.

The temperature rose to $107^{\circ} 6^{\circ}$ on the evening of the fifth day, and the reaction lasted to the ninth, after which the animal was normal. When tested with virus six days later the sheep was immune to gastro-enteritis.

Subinoculations made with blood collected on the seventh day proved the existence of this disease.

(C) Nine sheep, Nos. I 395 to I 403 , were received at the laboratory from Voi on 26th June I915, and experiments showed them to be suffering from gastro-enteritis. Ticks were collected on arrival.

(a) Seven nymphal rhipicephalus appendiculatus were obtained from Sheep I 399 and I 40 I, which died the following day.

Test.-Experiment 596. Three adult rhipicephalus appendiculatus collected as nymphæ from Sheep I 399 were applied to each of Sheep I 377 and 1408 on I 8 th September I9 I5, and one adult rhipicephalus appendiculatus collected from I $40 \mathrm{I}$ was placed on Sheep 1356 on the same date.

Sheep No. I 377 reacted $\left(105^{\circ}\right)$ on the sixth day, and died of gastro-enteritis on the twelfth. Subinoculations with blood drawn on the ninth day confirmed the diagnosis.

Sheep Nos. 1356 and I 408 showed no result up to the forty-second day, when they were tested for immunity. Both reacted normally and died.

(b) Five nymphal rhipicephalus appendiculatus were obtained from Nos. I 395 and I403, which died the day after collection, and two were collected off No. I 395, which had reacted prior to reaching the laboratory and was showing symptoms of diarrhoea; a subsequent test showed No. I 396 to be immune.

Test.-Experiment 622.- Eight adult rhipicephalus appendiculatus which fed as nymphæ on naturally affected sheep Nos. I 395, I 396, and I 403 were applied to Sheep I 5 I 5 on I 8 th October I9I 5 .

A typical temperature reaction commenced on the eighth day and lasted to the twelfth, when the animal recovered and was immune as shown by a subsequent test.

Blood drawn on the second day of reaction was shown to contain the virus of gastro-enteritis.

\section{Experiments with Laboratory-Bred Ticks.}

(I.) Can larval rhipicephalus appendiculatus born of mothers which fed on reacting sheep convey the disease?

Replete female rhipicephalus appendiculatus were obtained on arrival from Sheep I 395, I396, I 399 and I402, which were received 
from Voi in June I9I5, and were either suffering from, or had recently been affected with, gastro-enteritis naturally contracted there. Ova were laid and larvæ hatched in August I9I5.

Test.-Experiment 6I9.- I 8 th October I915. Sheep I 509 infested with larvæ born of rhipicephalus appendiculatus females collected from I395, which died the day after collection.

No reaction followed, and the sheep was shown to be immune when tested twenty-eight days later.

Sheep I 5 ro infested with larvæ of rhipicephalus appendiculatus collected as adults from I396, which had just recovered from the disease.

No reaction followed, and the sheep was shown susceptible and died when tested twenty-two days later.

Sheep I5I I infested with larvæ born of rhipicephalus appendiculatus females collected from 1399, which died the day after collection.

A temperature reaction commenced on the second day and lasted to the fifth, after which it continued normal to the twenty-sixth day, when death occurred from hæmonchiasis and peritonitis. Blood drawn on the second day of reaction demonstrated that this reaction was due to gastro-enteritis. Sheep I5I I had only arrived by train from Naivasha the day before this experiment was commenced, and as no cases to our knowledge ever occurred in the Rift Valley, the larvæ might conceivably be regarded as the cause of the infection. On the other hand, the incubation was shorter than in any other case of tick transmission, and more in keeping with an experimental inoculation. No opportunity has since presented itself of confirming this experiment, the result of which must remain doubtful.

Sheep I 512 infested with rhipicephalus appendiculatus larvæ born of females collected from Sheep I4O2, which had just recovered from the disease.

No reaction followed, and the sheep was shown susceptible and died when tested twenty-two days later.

(II.) Can nymphe rhipicephalus appendiculatus which were born of mothers feeding on sick animals, and which did not convey the disease at the larval stage, convey the infection?

Experiment 701.-16th December I9I 5. Larvæ were hatched from adult rhipicephalus appendiculatus collected from Sheep I 396, which had just recovered from a natural attack of the disease, and were fed on susceptible Sheep 15 Io without effect. (Vide supra, Experiment 6ig.) The engorged larvæ were collected and moulted early in December.

Test.-About 350 nymphæ were applied to Sheep 1562 on I6th December I9I 5 ; they attached readily, and 335 engorged specimens were collected between the fifth and thirteenth days.

A temperature reaction was shown on the eighth and ninth days, after which it returned to normal. Subinoculations made on the ninth day showed that this reaction was not due to the virus of gastro-enteritis, and when Sheep I 562 was tested on 2 Ist January I9I6, thirty-six days after ticks had been applied, it reacted normally 
between the third and seventh day, and was shown susceptible although recovery ensued.

(III.) Can rhipicephalus appendiculatus which fed as larve on a sheep reacting to gastro-enteritis convey infection as nymphe?

Experiment 553. - Sheep No. I 375 was inoculated on 9th July I9I 5 with the virus of gastro-enteritis, and larvæ born of female rhipicephalus appendiculatus collected off cattle at Molo, an area believed to be clean, were applied at the same time.

The temperature reaction began on the fourth day and lasted to the seventh, after which it remained about normal to death on the thirteenth day. The autopsy was indicative of gastro-enteritis, and blood drawn during the reaction was shown virulent.

Between the fifth day after inoculation (second of reaction) and the day of death I79 engorged larvæ were collected. About I20. moulted during the third week of August.

Test.-On 7 th September I9I5 twenty of these nymphæ were applied to each of sheep Nos. 749, I 350 and I 383 .

In each case the nymphr attached, and seventeen, sixteen, and fifteen engorged nymphæ, respectively, were collected between the fourth and twelfth days.

No temperature reactions followed. Sheep No. 749 died of œesophagostomiasis thirty-three days later, and Nos. 1350 and 1383, when tested on the thirty-third and forty-eighth days, both reacted normally and died of gastro-enteritis.

(IV.) Can rhipicephalus appendiculatus which fed as larve on a reacting sheep, and failed to transmit infection as nymphe, convey the disease in the adult stage?

Experiment 553.-Larvæ born of rhipicephalus appendiculatus obtained from cattle at Molo were fed on Sheep 1375 throughout the reaction, and after moulting were fed, without result, upon Sheep 749, I350 and I383 (vide supra). Forty-eight engorged nymphæe were collected up to Igth September I9I5, and moulted three weeks later.

Test.-On I 8 th October 19I 5 twenty adult rhipicephalus appendiculatus obtained as above were applied to each of Sheep I5I4 and 1516 , and attached themselves to the ears.

No temperature reaction followed in either animal to the fourteenth day, when they were tested for immunity. Both reacted normally to gastro-enteritis, No. 15 I4 dying of that disease on the eighth day, while No. I5I6 recovered. The blood of both was proved virulent on subinoculation.

(V.) Can rhipicephalus appendiculatus which fed as nymphe on a reacting sheep transmit the disease as adults?

(a) Experiment 631.-Rhipicephalus appendiculatus larvæ born of mothers collected from cattle arriving from Uganda were fed on Sheep I 402, immune to gastro-enteritis, and were obtained engorged between the 3 rd and 9 th October I9I 5 .

On $9^{\text {th }}$ November I 9 I 5 about IoO nymphæ were applied to Sheep I 5 IO, I 5 I 2 and I525, which were inoculated at the same time with 
virus. Nos. I 510 and I 5 I 2 died on the fifth and sixth days, and no engorged nymphæ were recovered.

No. I 525 reacted to inoculation between the third and eighth days, and recovery resulted. The nymphæ were attached, but fed badly, and only thirteen engorged specimens were recovered between the eighth and fifteenth days.

Test.-Six adults emerged about the middle of December, a month later, and three were applied to each Sheep 1577 and 1606.

No reaction occurred in No. 1577 , which was subsequently shown susceptible, and only one tick was seen attached.

Two adults were attached to Sheep I606 two days after application, and one was still there on the tenth day. A temperature reaction commenced on the sixteenth and lasted to the twentysecond day, after which it returned to normal and the sheep recovered. Blood drawn on the second and fourth days of the reaction showed this to be due to gastro-enteritis.

(b) Experiment 790.--Larvæ born of mother collected from Sheep 1395, which died the day following collection, were fed without result on Sheep 1509. (Vide supra, Experiment 619.) The engorged larvæ moulted in November 1915 , and the nymphæ were applied to Sheep I568 on I6th December I9I5, the animal being inoculated with gastro-enteritis at the same time.

A typical reaction commenced on the third day and lasted to the seventh, after which the temperature became normal and the sheep recovered.

The nymphæ attached well, and between the fifth and thirteenth day after inoculation seventy engorged specimens were obtained.

Test.-On toth April I9I6 about thirty adults, collected as above, were applied to each Sheep 1600 and 1686, and four and eight respectively were found attached two days later.

No. 1686 showed a temperature reaction between the sixth and ninth days, but of less intensity than usual, reaching only $105^{\circ} \mathrm{F}$. (normal of this sheep $I_{O}{ }^{\circ} \mathrm{F}$.), and as a consequence the animal was not bled. When subsequently tested it was found immune, and it is therefore probable that this reaction was due to the disease caused by tick infection.

No. I60o did not manifest any reaction, and was shown susceptible and died when tested.

\section{(VI.) Immunity.}

An animal which has recovered from the natural or the experimental disease does not react to a second infection if made within a few months. The exact duration of this immunity has not yet been ascertained, but the following experiment indicates that it may exist for several years. The Kikuyu natives consider that an animal can only be attacked once.

Sheep 304 and 312, Grade animals, were inoculated on 28th August I9I I, reacted normally, and recovered.

On Ioth February 1915, forty months later, each received a mass injection of $300 \mathrm{cc}$. virulent blood subcutaneously.

In No. 304 the temperature rose gradually to the fourth day and fell suddenly to normal. In No. 312 there was a slight elevation from the sixth to the ninth day. 
Blood drawn from these sheep on the fourth day was non-infective, and the reaction is considered to have been due to traumatism and absorption.

Attention has already been drawn to the much greater resistance enjoyed by Grade and Pure-bred sheep reared in districts where the disease is unknown as compared with native animals. Figures referring to the first $\mathbf{2 2 4}$ sheep experimented upon have been quoted, which showed that, although the incidence of temperature reaction was the same in all, the mortality was $7 \mathrm{I}$ per cent. in natives and only $3 \mathrm{I}$ per cent. in Grade and Pure-bred sheep.

From the condition obtaining in the Kikuyu Native Reserve it is obvious that infection is very localised, for, although we have never failed to obtain the disease when required by exposing animals to graze there, many of the sheep bought from natives living on the same land have been shown susceptible. This would appear to be due to certain restrictions in grazing and herding adopted by the natives, and meets with a parallel case in East Coast fever, which also occurs in the Reserve, causing heavy losses among calves of one small village, and not spreading readily to others only a few hundred yards distant.

Artificial Immunisation.-The experiments made in an endeavour to find a method whereby sheep could be protected against this disease were undertaken before the exact mode of spread had been ascertained or the distribution in the Protectorate was in any way known.

Attenuation by heat did not yield encouraging results (vide Resistance of Virus, page 39), nor did the use of a serum made in sheep against the virus of gastro-enteritis.

Antiserum Preparation.-Serum was prepared in immune sheep by subcutaneous, intraperitoneal, and intramuscular injections of citrated virulent blood in doses up to $500 \mathrm{cc}$. In most cases the subcutaneous method was followed, and an immune animal received at once between 100 and 500 cc., followed at variable intervals by other doses of similar amounts. The animals were bled about a fortnight after the last injection, and a further maximum injection was made if necessary.

The sera obtained from each animal, or from a series of animals, after each hyperimmunising were kept separate and used in independent tests, either alone or in association with virus given simultaneously or at variable intervals later.

No clearly satisfactory results were obtained. It appeared that when sheep were strongly hyperimmunised the sera acquired hæmolytic properties and killed a higher proportion of animals than it saved; and if fortification was not intense it possessed little or no prophylactic powers.

As the object of this work was to devise measures which would safeguard a sheep-owner should the disease gain entrance to his flocks, it became apparent that serum prophylaxis, entailing the manufacture of expensive serum, would not be a.practicable method except in extreme cases. Further, additional research indicated that the disease did not exist in the districts wherein sheep farming was extensively carried on, and as this line of preventive treatment 
could not yet be applied to the native Reserves the enquiry was suspended.

The question of hremolysis is one of extreme interest, and may become one of great importance in connection with this and other diseases in which antisera may be employed. It is well known from the researches of Theiler that it plays a very important part in the preparation of serum against horse sickness, which also has an "ultravisible" virus; and, as in that disease, the hæmolytic effect is reproduced by homologous sera, i.e., horses hyperimmunised with horse blood, and sheep with sheep blood. In the manufacture of rinderpest and other bovine antiserum no parallel case has yet come under notice.

Unfortunately no detailed work on this condition could be undertaken, but the following experiments will indicate the existence and importance of the phenomenon, and draw attention to the peculiar feature that the reaction appeared to cease when serum shown to be hremolytic was kept for about a year.

Blood was collected in serum flasks, and the serum decanted fortyeight hours later, and carbolised to the extent of 5 per cent. prior to use.

Symptoms and Post-mortem Appearances of Hamolysis in Sheep.Nine sheep died from hæmolysis, following injection of six separate sera and one pooled serum, in doses of from ro to $50 \mathrm{cc}$. Death occurred in from 12 to I68 hours.

In the acute cases, i.e., with death within twenty-four hours, the sheep were noted as dull and not feeding, lying down with head extended, increased respirations, which became very shallow and were interspersed with deep expiratory gasps. In most animals a watery diarrhoea occurred, fæces being passed in small quantities and frequently. The urine was bright red in colour and voided at short intervals. The visible mucous membranes were extremely pale. These symptoms became aggravated, the animal passing into a state of coma, with oral breathing and subnormal temperature, to death.

No careful observations were made to note the time after injection when symptoms first appeared; but they have been seen within five hours, and the sheep have died eight hours later.

On post-mortem examination the subcutaneous tissues were hæmoglobin-stained, and the peritoneum usually contained a large amount of blood-coloured fluid.

The abomasum and intestinal tract were empty or contained only watery contents, the mucosa oedematous and studded with hæmorrhagic foci, sometimes aggregated to form striæ. The liver and kidneys were pale, swollen, and friable; the spleen much enlarged, soft, and dark and tarry on section.

The bladder contained hæmoglobin-coloured urine.

The thorax contained an excess of fluid, usually blood-stained.

The lungs were often of a dirty yellow-brown colour, and very frequently odematous. The heart was pale, flaccid, and often ecchymosed under the epicardium.

In the subacute form, with death after twenty-four hours, symptoms are manifested within a day of inoculation, but are more gradual in their development. The sheep is dull and not feeding, respirations 
are increased and shallow, and in some cases diarrhoea was noted Towards the end the animal became comatose.

No cases of recovery from this condition have been noted.

On autopsy the subcutaneous tissues and abdominal fat were stained a bright ochreous yellow. The intestinal tract was normal or showed slight œdema of the mucosa. The liver and kidneys pale but fairly firm. The spleen swollen but pale and with very prominent Malpighian bodies. The bladder usually contained hæmoglobinstained urine, but in a few instances the contents were of varying degrees of yellow to brown.

In the thorax, the lungs were of a brownish-yellow colour and commonly odematous : the heart soft.

The peritoneal, pleural, and pericardial cavities usually contained an excess of fluid, most often of a deep straw-colour, less commonly hæmoglobin-stained.

\section{Serum Test No. I.}

This serum was made as follows :-

Immune Sheep 19 injected subcutaneously 300 cc. Bled fourteen days later.

Immune Sheep 36 injected subcutaneously $100: 100: 300 \mathrm{cc}$. at twenty-one day intervals. Bled fourteen days later.

Immune Sheep 67 injected subcutaneously $100: 300 \mathrm{cc}$. at twentyone day intervals. Bled fourteen days later.

Immune Sheep 99 injected subcutaneously $100: 300 \mathrm{cc}$. at twentyone day intervals. Bled fourteen days later.

Immune Sheep ro3 injected subcutaneously I00: $500 \mathrm{cc}$. at thirtyfour day intervals. Bled fourteen days later.

Immune Sheep 107 injected subcutaneously $100: 500 \mathrm{cc}$. at thirtyfour day intervals. Bled fourteen days later.

Tests.-(I) Serum of Sheep 36.

Native Sheep 152 received Io cc. subcutaneously. Died hæmolysis in 120 hours.

Native Sheep I 7 I received I 5 cc. subcutaneously. Died hæmolysis in twenty-four hours.

Native Sheep 172 received $20 \mathrm{cc}$. subcutaneously and virus fourteen days later. Died of gastro-enteritis.

Native Sheep 2 I 8 received 50 cc. subcutaneously. Died hæmolysis in eighty hours.

(2) Serum of Sheep 67.-Native Sheep I 35 and I 56 received $5 \mathrm{cc}$. subcutaneously and 2 cc. virus simultaneously. Both died of gastro-enteritis.

Native Sheep I 58 and 164 received Io cc. subcutaneously and $2 \mathrm{cc}$. virus simultaneously. No. I5 8 died of gastro-enteritis; No. 164 showed severe reaction and recovered.

Native Sheep I 47 and I 55 received I 5 cc. subcutaneously and $2 \mathrm{cc}$. virus simultaneously. Both died of gastro-enteritis.

Native Sheep I 59 and 163 received $20 \mathrm{cc}$. subcutaneously and $2 \mathrm{cc}$. virus simultaneously. No. I 59 showed a slight reaction and recovered; No. 163 died of gastro-enteritis.

Native Sheep I 77 and 178 received $50 \mathrm{cc}$. subcutaneously and $2 \mathrm{cc}$. virus twenty-four hours later. No. I 77 showed a slight reaction and recovered; No. 178 died of gastro-enteritis. 
(3) Serum of Sheep 99.-Native Sheep 222 received 50 cc. subcutaneously. There was no hæmolysis.

(4) Serum of Sheep I03.-Native Sheep 2 I9 received $50 \mathrm{cc}$. subcutaneously. Death from hæmolysis in fifty-four hours.

(5) Serum of Sheep 107.--Native Sheep 226 received $50 \mathrm{cc}$. subcutaneously. Death from hamolysis in fifty-four hours.

(6) Sera of Sheep 19, 36 and 67 mixed in equal parts.-Merino Sheep Nos. 5 and 7 , and Native Sheep Nos. 195 and 202 each received 50 cc. subcutaneously. No. 5 died of hæmolysis in I 20 hours; the other three died of hæmolysis within twelve hours.

This mixed serum was allowed to stand in the serum room from March I9II, when the above experiment was made, until February 1912, when it was tested first on two sheep in doses of $50 \mathrm{cc}$. without manifesting hæmolytic action, and later in the following manner on native sheep.

Result.

\begin{tabular}{|c|c|c|c|}
\hline $\begin{array}{l}\text { Number of } \\
\text { Sheep. }\end{array}$ & Dose of Serum. & $\begin{array}{c}\text { Deaths from } \\
\text { Gastro-Enteritis. }\end{array}$ & Recovery. \\
\hline 4 & $\begin{array}{l}\text { Io cc. and virus } \\
\text { simultaneously }\end{array}$ & $\mathbf{I}$ & 3 \\
\hline 5 & $20 \mathrm{cc} . \quad$ do. & 3 & 2 \\
\hline 2 & $30 \mathrm{cc} . \quad$ do. & 0 & 2 \\
\hline I I & & 4 & 7 \\
\hline
\end{tabular}

Serum Test No. 2.

This serum was prepared as follows:-

Immune Sheep 26I and 315 were injected subcutaneously with $300 \mathrm{cc}$. virulent blood and bled sixteen days later.

The following test was made with the freshly mixed serum :-

\begin{tabular}{|c|c|c|c|}
\hline $\begin{array}{l}\text { Number of } \\
\text { Sheep. }\end{array}$ & Dose of Serum. & $\begin{array}{c}\text { Deaths from } \\
\text { Gastro-Enteritis. }\end{array}$ & Other Causes. \\
\hline 2 & $\begin{array}{l}\text { Io cc. and virus } \\
\text { simultaneously }\end{array}$ & 2 & o \\
\hline 2 & $20 \mathrm{cc} . \quad \mathrm{do}$. & I & I pneumonia \\
\hline 2 & $5 \circ \mathrm{cc} . \quad$ do. & 2 & 0 \\
\hline 6 & & 5 & $\mathbf{I}$ \\
\hline
\end{tabular}

Serum Test No. 3 .

This serum was prepared as follows:

Immune Sheep 264, 269 and 295 were each injected subcutane- 
ously with $300 \mathrm{cc}$. virulent blood and bled eleven and twenty-five days later, and the yields mixed.

Tests for hæmolysis were made with each serum in doses of $50 \mathrm{cc}$. subcutaneously.

\begin{tabular}{c|c|l}
\hline Serum of. & Sheep No. & \multicolumn{1}{c}{ Result. } \\
\cline { 1 - 2 } 264 & 406 & Death from hæmolysis in seven days. \\
20 & 464 & Nil. \\
269 & 426 & Death from hæmolysis in eighty hours. \\
295 & 465 & Nil. \\
$"$ & 405 & Nil. \\
\hline
\end{tabular}

\section{Serum Test No. 4 .}

Six native sheep, which reacted to gastro-enteritis but recovered spontaneously and were not hyperimmunised, were bled between the fourth and the twelfth day after the temperature returned to normal. These sera were mixed and tested for hæmolytic and prophylactic properties. Virus was injected twenty-four hours after the serum, which was given in a dose of $20 \mathrm{cc}$.

Twelve native sheep were employed. Seven ( 58 per cent.) died of gastro-enteritis, the course and duration being uninfluenced by the serum. Five, or $4 \mathrm{I}$ per cent., recovered and were immune.

Attenuation by Passage through Goats.-It has been noted that although goats are susceptible to infection with this disease the mortality in them is much less than in sheep.

In the Kikuyu Reserve this animal exists in numbers considerably greater than sheep, and it was considered possible that by several passages of virus through caprines the virus might become attenuated.

At the time the tentative experiment was undertaken only a limited supply of goats and sheep was available, and it was not possible to control the result in such a manner as was desirable.

\section{Experiments 703, 709, 710 and 728. (See Chart-Sheep I I 52.)}

The virus of gastro-enteritis was passed through seven generations of Grade Angora goats coming from Naivasha; each generation consisted of two animals, and five days after injection these animals were bled, irrespective of temperature, and the pooled blood was inoculated subcutaneously into two more goats.

Tests into two sheep were made after each passage except the second, two animals being used for each except for the sixth, when four were inoculated.

Sixteen sheep were therefore employed, of which, however, three died of a heartwater-like disease from which they were suffering on arrival. Of the thirteen animals exposed to gastro-enteritis alone, two died of that disease-an average of $15^{\circ} 3$ per cent.

As the mortality even among Grades and Merinos exceeds 30 per cent., this figure represents a substantial reduction, and, although no deduction should be drawn from this single experiment, there is 
sufficient indication to justify a further observation on a more extended scale.

\section{VII.-Prevention.}

As the mortality from this condition affects primarily trade sheep and native-owned animals within the Reserve, little benefit can result except by the prohibition of movement of affected mobs, or of clean mobs introduced to infected areas. It is doubtful if such restrictions could be enforced without imposing upon the population who engage in this trade very considerable loss. Individual owners of land where rhipicephalus appendiculatus exists should not permit the entry of doubtful sheep until they have undergone a quarantine of at least twenty-one days without any deaths occurring from this disease. The sheep might then be introduced. Should deaths occur, the quarantine area grazed over must be regarded as infected ; and, though the sheep can then be moved without fear, it should be

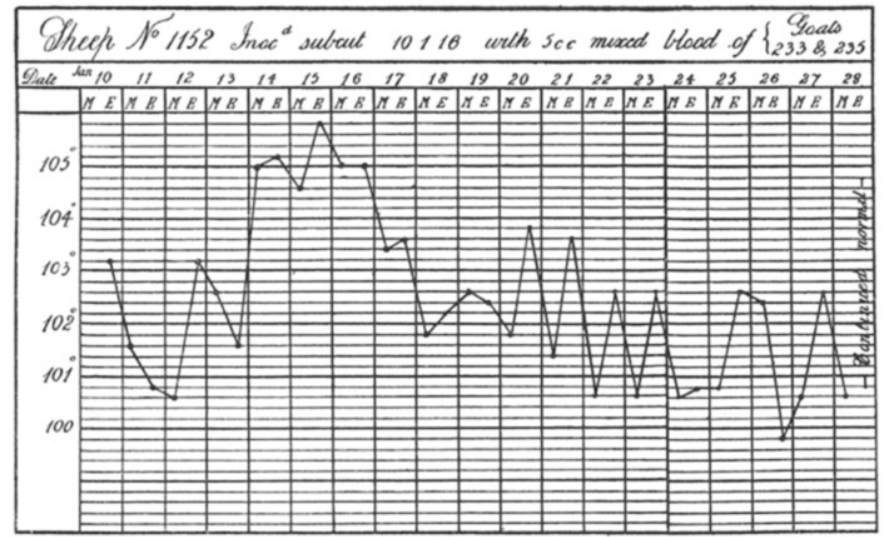

Chart. Sheep 1152.

destocked of sheep and goats for eighteen months, and grazed with cattle only for that period.

As in most cases the sheep are infected while passing through the Kikuyu country to Nairobi and the farms, purchasers should realise that the animals are probably diseased when bought, and be prepared to lose the number actually infected; but by the adoption of a quarantine camp further infection could be checked.

Our experiments indicate that rhipicephalus appendiculatus is the tick incriminated in this condition; there may be others, but in most of the tick-borne diseases transmission is restricted to one species or a series of closely related forms.

Paucity of rhipicephalus in some parts of the Protectorate will act as a natural barrier to the extensive spread of the disease there.

\section{DIPPING.}

During the outbreak on a farm near the laboratory (see page 43) when muzzled and unmuzzled sheep were exposed to contract the disease, the following experiment was undertaken. 


\section{Experiment 369.}

Three Native Sheep 1022, I023, and 1028 were dipped for one minute in Standard Cooper's Powder Sheep-dip bath on two successive days and left undipped for two days. This was continued until infection had been acquired by two. The sheep were exposed to the area immediately after the first dipping, and, as controls, the sheep of Experiments 366 (first series) (page 43) and 367 (page 44) were sent in company to the infected area.

The result of these three experiments may be read together.

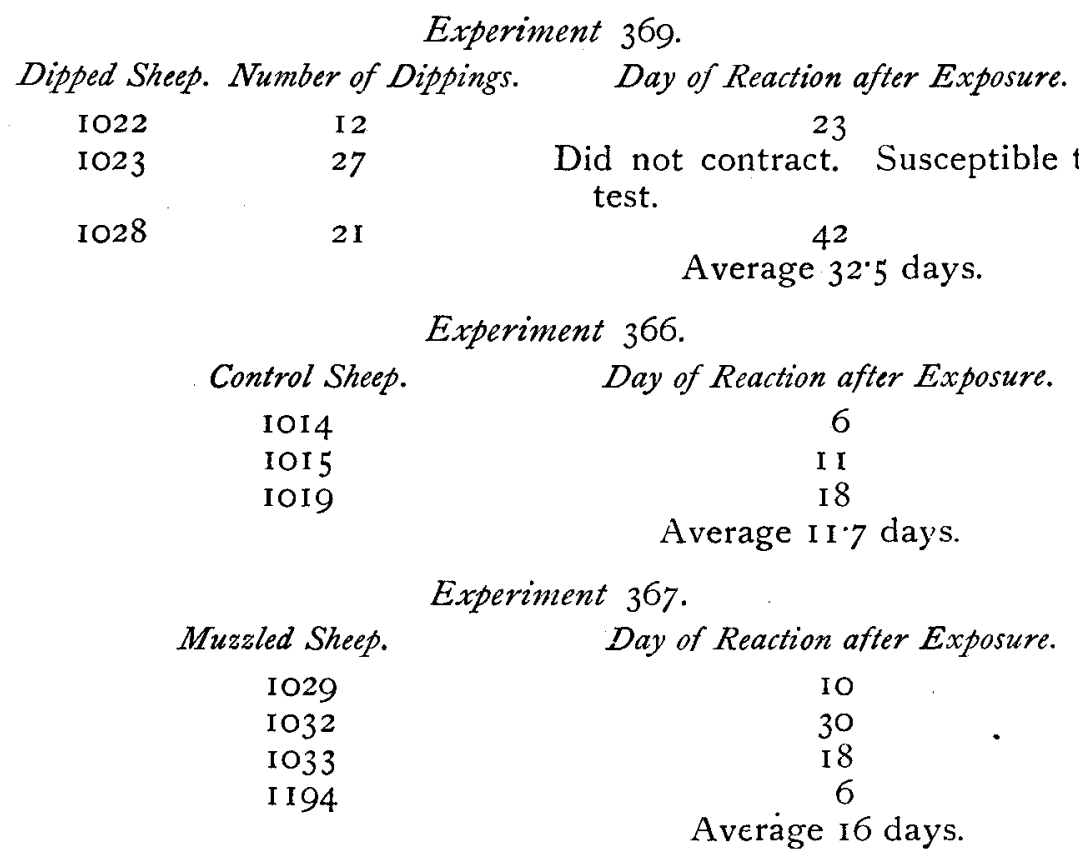

From this experiment it might fairly be considered that this dipping was beneficial.

\section{SUMMARY AND CONCLUSIONS.}

Hæmorrhagic gastro-enteritis occurs principally in the Kikuyu country, where it would appear to be enzootic, manifesting itself as an epizootic only when large mobs of susceptible animals are exposed to infection.

Sheep and goats alone appear to be susceptible-the former to a much greater extent. Grade and Pure-bred sheep enjoy a resistance considerably more marked than the native sheep, in which the mortality is about 70 per cent. of those attacked.

The disease is carried by the "brown" tick, rhipicephalus appendiculatus. No other tick has yet been proved, but further work is required to negative the possibility. It would appear that adult ticks which in their preceding stage (nymphæ) have fed on affected sheep can carry the infection after moulting. It is possible that larva born of a female feeding on a sick animal may also transmit the disease, but on this point the evidence is more scanty. 
No success has yet been attained by different methods of preventive inoculation. The most favourable line appears to be by attenuating the virulence of the disease for sheep by passing the virus for several generations through the more resistant goat.

The eradication of ticks capable of carrying the disease should form the basis of preventive measures.

Rhipicephalus appendiculatus is also the carrier of East Coast fever in cattle, and for its eradication cattle must be dipped every three days.

There is no doubt that dipping cattle at a three-day interval will very greatly clear the ground of all ticks, and in their absence gastro-enteritis of sheep cannot spread.

\title{
TUBERCULOUS MASTITIS IN THE COW: ITS PATHOGENESIS, AND MORBID ANATOMY AND HISTOLOGY.
}

\author{
By Sir John M‘Fadyean, M.B،, B.Sc., LL.D., Royal Veterinary \\ College, London.
}

\section{I.-PATHOGENESIS.}

OPINION with regard to the manner in which the cow's udder becomes infected with tubercle bacilli is divided. It is generally agreed that in a small minority of cases infection takes place directly by way of the canal of one of the teats, but there are two sharply opposed views regarding the route by which the bacilli arrive in the gland in the remaining cases.

The Common Method of Infection.--One of the views is that in all cases except those of direct infection the bacilli reach the udder in the arterial blood, having been transported by this means from some pre-existing tuberculous lesion elsewhere in the body-usually in the lungs. The other view is that, in regard to its starting point, tuberculous mastitis is an example of what is conveniently termed I centrifugal lymphatic infection; in other words, that the bacilli are transported by way of the lymphatic vessels from a pre-existing lesion in the abdomen, and thus in a direction contrary to that in which the lymph is supposed to flow in normal circumstances.

The first of these theories with regard to the most frequent method of infection is in my opinion erroneous. It must be admitted, however, that it deserves to be called the orthodox view; indeed, I do not know an author who does not express or adopt it if he deals with the point at all. It may suffice to quote only two examples.

Wall, in his monograph on the inflammations of the cow's udder, ${ }^{1}$ thus refers to the methods of infection in tuberculous mastitis :-

"Infection by way of the blood is the commonest. It is a consequence of pulmonary tuberculosis with blood infection through ulceration into the veins.

"When the blood infection is derived from another organ (in

1 Die Euterentzündungen der Kuh. Von Sren Wall, 1908, p. 66. 